\title{
Goldin wants more NASA biologists as Gore is briefed on space plans
}

Washington. Dan Goldin, administrator of the US National Aeronautics and Space Administration (NASA), said last week that the agency should significantly increase its research on astrobiology - the science of the origins of life - and employ more biologists.

Goldin was speaking after a meeting of leading space scientists with $\mathrm{Al}$ Gore, the US vice-president, which not only covered recent and possible future discoveries in space science but also addressed their potential religious and philosophical implications.

"We were working around the core theme of origins, including the origins of life," said one participant, Claude Canizares of the Massachusetts Institute of Technology, who chairs a National Academy of Sciences space studies board. He said the religious perspective was required because "this touches on the most profound philosophical questions".

The meeting had been organized to brief Gore on the US space science programme in preparation for a US 'space summit' in February. Among those invited to participate were John Minogue, a theologian and president of DePaul University in Chicago, Stephen Jay Gould, the evolutionary biologist, and Carl Sagan, the popular astronomer and author (although Sagan was ill and unable to attend).

The two-and-a-half hour meeting was described by officials as a wide-ranging discussion, led by Gore, of the "philosophical underpinnings" of space science, which steered clear of specifics. But Goldin said that the meeting had taught him that the space agency's small programme in astrobiology should be expanded.

"It became clear to me that the astrobiology programme is desperately underfunded," Goldin said. "We had better look at our science on the origins of life, before we go building more spacecraft."

Warming to this theme, Goldin said that life scientists are underrepresented at NASA's research centres. "We have too many people in chemistry and physics," he said, adding that in future the agency "will be led by two disciplines - information science and biology".

NASA currently has a small programme in the new discipline of astrobiology at the Ames Research Centre in California, led by David Morrison. A spokesman at NASA headquarters in Washington was unable to provide a detailed breakdown of the agency's current research or staff by scientific discipline.

Jack Gibbons, science adviser to President Bill Clinton, says last week's meeting did not discuss programmes or budgets. $\mathrm{He}$ also plays down expectations that the summit will make decisions on specific programmes. "I'm not optimistic we will get that degree of specificity by February," he says. The summit will bring Clinton and Gore

\section{NIH drops plan for multiyear grants}

Washington. The US National Institutes of Health $(\mathrm{NIH})$ has abandoned a plan to issue some young researchers with multiyear grants after lawyers at the Department of Health and Human Services said that it would breach departmental regulations.

The reversal means that the NIH will now have to spend all of its 1997 research funds next year - rather than holding some back to pay for research in future years - so boosting the number of grants it will make.

The biomedical research agency's plan had been to select about 250 young investigators and support them for two or three years. But it decided to drop the idea when lawyers advised that it would have to give multiyear grants to all the successful applicants for certain categories of grants or to none at all.
NIH had argued that the multiyear grants would guarantee recipients that they would continue to receive funding, and would prevent the agency from issuing too many new grants in 1997 - a year for which the agency has received a generous funding increase. But biomedical lobbyists attacked the idea on the grounds that it would allow NIH to avoid spending all of the money that Congress has given it to spend, so weakening its case for more money in subsequent years (see Nature 384, 203; 1996).

Wendy Baldwin, deputy director for extramural research at NIH, says that the policy change came about "abruptly" at a time when the agency's institutes had been working out how to issue the multiyear grants. A handful have already been awarded, and these will now be given as single-year grants.

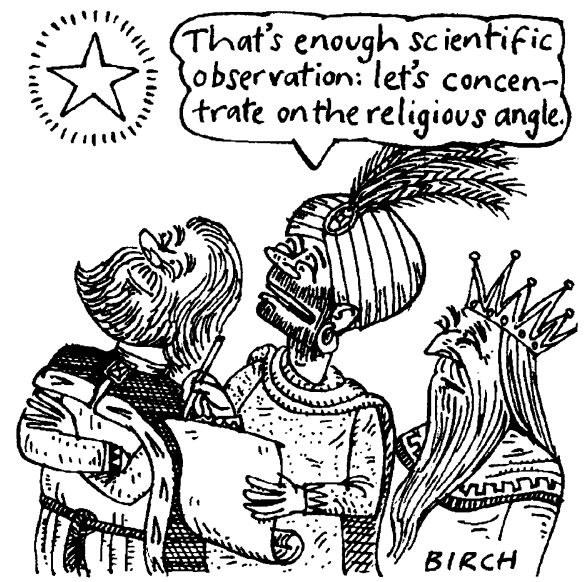

together with congressional leaders to discuss an impending budget squeeze at NASA.

The summit was first proposed by Senator Barbara Mikulski (Democrat, Maryland), a NASA supporter, and agreed to by Clinton in August, when the agency's scientists claimed to have found evidence of life on meteorites that originated on Mars.

The group of 20 that met Gore last week also included David McKay of the NASA Johnson Space Center in Texas, lead author of the meteorite paper (Science 273, 924; 1996); Bill Moyers, a television commentator; Stuart Kauffman of the Santa Fe Institute, an expert on complexity theory; and Anneila Sargent of the California Institute of Technology, who chairs NASA's space science advisory board.

The presence of religious leaders indicates the significance now attached to this aspect of space exploration. "Many Americans believe in God," said Goldin. "Taxpayer funds are involved here and it is crucial that science is not operating in a vacuum."

But Gould is sceptical. "We should acknowledge that religion and science are different enterprises that do not intersect," he says. Science oversteps its boundaries, he suggests, "when it tries to talk about the fundamental nature of the Universe", and religion oversteps its own when it asserts that nothing is more than 10,000 years old.

Gore's unusually prominent role in the Clinton administration - his responsibilities include environmental policy and relations with Russia - is further enhanced by the expectation that he will mount a formidable bid for the presidency in 2000 . His strong intellectual grasp of the issues made a deep impact on delegates at last week's meeting. "There wasn't a scientist in the room who was not impressed," says Sargent.

Colin Macilwain 